\title{
The Psocoptera of Norway spruce (Picea abies) branches in northern Finland
}

\author{
Anne Laine, Juhani Itämies \& Markku Orell
}

Laine, A., Itämies, J. \& Orell, M. 1993: The Psocoptera of Norway spruce (Picea abies) branches in northern Finland. - Entomol. Fennica 4:201-206.

The psocid fauna living on spruce branches was studied in northern Finland, both in urban areas near the industrial city of Oulu and in rural surroundings, during the years 1986-88. Samples of about 6000 psocids of 19 species were taken from old and young spruces. The psocid assemblage of the rural area of Taivalkoski differed significantly from other areas according to the pooled data of old spruces. Mesopsocus unipunctatus (Müller), Caecilius burmeisteri Brauer and Trichadenotecnum majus (Kolbe) were most numerous in the most urban areas, Reuterella helvimacula (Enderlein) in the areas characterized by the epiphytic lichen Hypogymnia physodes.

Anne Laine, Juhani Itämies \& Markku Orell, Department of Zoology, University of Oulu, P.O.Box 333, FIN-90571 Oulu, Finland

\section{Introduction}

In Finland 61 species of psocids (Psocoptera) belonging to 16 families have been encountered (Huldén 1984). Little is known of their occurrence on conifer trees, especially in northern Finland. A number of arboreal species are found either on bark (e.g. Psocidae, Philotarsidae and Peripsocidae) or on the foliage (e.g. Caeciliidae and Stenopsocidae) of various tree species (New 1971, Thornton 1985) and they can be grouped into "conifer species" and "broad leaved species" according to Thornton (1985). Arboreal psocids are mostly grazers which feed on microepiphytes. Some take pollen grains as well (Thornton 1985).

In 1986 we started to examine the composition of the invertebrate fauna living on both old and young Norway spruce branches (Picea abies) in urban and rural surroundings in northern Finland (Laine et al. 1990). Some preparatory attention was given to the possible effects of air impurities on the spruce invertebrate fauna. In this paper the results concerning psocids are reviewed.

\section{Material and methods}

\subsection{Old spruces}

Old spruce samples were taken in four forests (Fig. 1). At Linnanmaa, $5 \mathrm{~km}$ from the centre of the city of Oulu the study area was sparse sprucedominated mixed forest situating on boggy ground. At Sanginjoki, $15 \mathrm{~km}$ from the centre of the city of Oulu the study plot was situated on a south facing forested slope. The study plot in the commune of Muhos, $30 \mathrm{~km}$ from Oulu, consisted of two forest islands surrounded by pine bogs. The old spruce stand at the Taivalkoski rural district, $150 \mathrm{~km}$ from Oulu, was on a north facing hill.

The samples (one branch per an old spruce; five samples per study plot) were collected on 


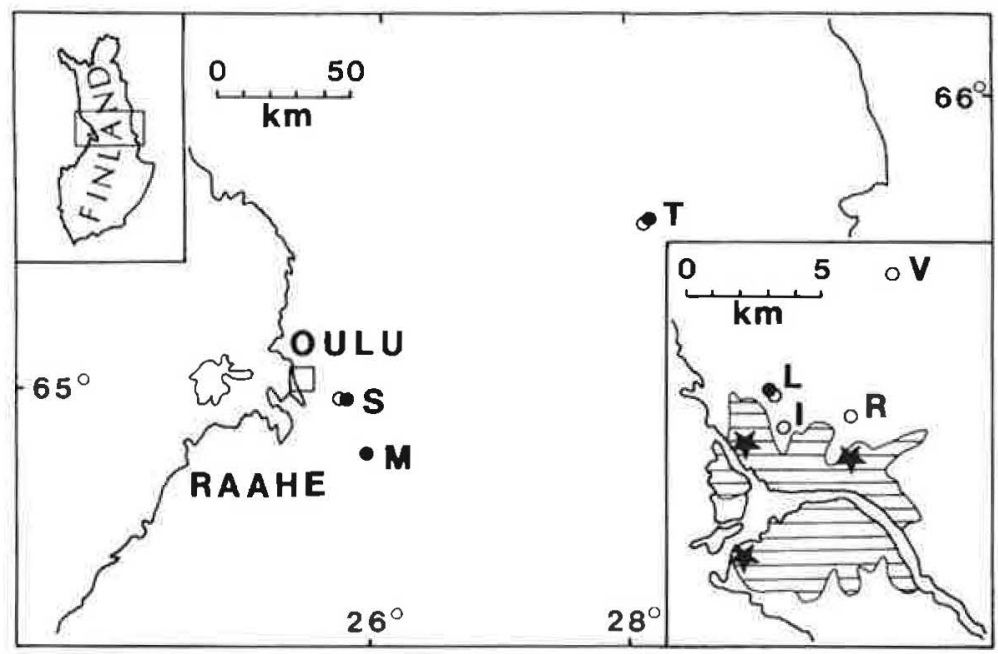

Fig. 1. The research areas of $1986-87$ are represented by black dots: $L=$ Linnanmaa (Grid $27^{\circ} \mathrm{E} ;(721: 42), \mathrm{S}=$ Sanginjoki (721:44), $M=$ Muhos (720:45), $T=$ Taivalkoski (727:56). The research areas of 1988 are represented by open circles: $R=$ Rusko (721:43), I = Isko (721:42), L = Linnanmaa, $V=$ Vittasuo (722:43), $S$ = Sanginjoki and $\mathrm{T}=$ Taivalkoski. Major pollution sources are represented by stars. Prevailing winds in the area are $\mathrm{W}, \mathrm{SW}$, spreading air impurities of the industrial cities of Oulu (pulp and fertilizer industry) and Raahe (iron and steel works) mostly eastwards.

average once a month in 1986. In 1987 samples were taken three times (January, June and September) from these plots. Branches about $2 \mathrm{~m}$ in length and $1.5 \mathrm{~kg}$ in dry weight were cut from the lower parts of ca. 100 year old, on average 10-15 $\mathrm{m}$ high spruces. Before cutting, the branch was covered by a plastic bag.

In the laboratory adult psocids and most of the juveniles were removed manually. The lichens and pieces of branches were kept in extracting cylinders for four weeks. During the extraction the branch material slowly dried and the rest of the psocids fell into collecting jars. After extraction the wood material, needles and lichens were weighed. The term dry weight refers to material dried in this way.

\subsection{Young spruces}

In 1988 branches from young spruces were collected at six study areas (Fig. 1). Linnanmaa was the same area as in the previous years. The suburb of Isko had a stand of old mixed coniferous forest bordering a highway. The sample plot in the Rusko suburb was situated in a damp mixed forest of birches and spruces. The Vittasuo area outside the city of Oulu was dominated by birch saplings (Betula pubescens) under large old spruces. In the Sanginjoki research area young pine trees dominated. In the Taivalkoski rural district the samples were taken in a young sapling stand of spruces with mixed birch saplings located on the west facing slope of Romevaara hill.

The samples (3-4 branches per spruce; ten spruces per study plot) were collected once a month in May-September using the methods described above. They were taken from 20-30 year old and 2-3 $\mathrm{m}$ high spruces. For total sulphur and nitrogen analyses separate needles from the 1987 shoots were collected. They were dried at $+60^{\circ} \mathrm{C}$, powdered and analyzed in the Kemira Corporation laboratory in Oulu, using Leco(sulphur) and Kjelldahl analysers (nitrogen).

\subsection{Psocid material}

The species were identified mainly with the guide compiled by Günther (1974). The nomenclature follows the work of Huldén (1984). The material is deposited in the collection of the zoological museum of Oulu. 


\subsection{Statistical methods}

The rarefaction method (Heck et al. 1975, James \& Rathbun 1981) was adopted in comparing the number of species in the pooled material. In comparisons of the species composition of the different study plots the Renkonen (1938) index of percentage similarity was used. Before calculations the data were transformed on to a logarithmic scale as recommended by Wolda (1981). The index was calculated as follows:

$$
\mathrm{PS}=\min \left(p_{i j}, p_{i k}\right) \text {, }
$$

where $p_{i j}, p_{i k}$ is the proportion of the species $i$ in samples $j$ and $k$. The standard error of the index can be derived from the formula for estimating confidence limits for the index (Pesenko 1982):

$$
\mathrm{PS} \pm t_{s i} \sqrt{\min \left(m_{i j}^{2}, m_{i k}^{2}\right)}
$$

where $t_{s t}=t$ value corresponding to significance level st, $\mathrm{m}_{\mathrm{ij}}^{\mathrm{st}}=\sqrt{p_{i j}\left(1-p_{i j}\right) / N_{j}}$ and $N_{j}=$ the total number of individuals ( $\log 10$ scale) in sample $j$.

Faunal similarity was studied by means of the $t$-test. In the final examination pooled data was used as the number of individuals was too low to compare the samples of different months. As the dry weight of wood material did not differ between areas no psocid indices or densities were calculated.

\section{Results}

There were differences between the areas in the occurrence of epiphytic lichens on old spruces (Table 1). On young spruce branches there were no meas- urable amounts of lichens. Total sulphur and nitrogen concentrations, which were measured only from young spruces, were highest in the plots located closest to the city centre (Rusko, Isko and Linnanmaa), descending towards the more rural areas.

On old spruces 5542 psocids belonging to 16 species were obtained from a total of 270 branches with a dry weight of $237 \mathrm{~kg}$ (Table 2), 63\% being juveniles. The five most abundant species comprised $88 \%$ of the adult psocids. During winter only juveniles and females of Reuterella helvimacula were obtained. Psocids were most numerous at Linnanmaa near the city centre of Oulu and their number was lowest at Taivalkoski (Table 2). There were no differences in the species richnesses between Linnanmaa, Sanginjoki and Muhos when based on rarefaction curves (Fig. 2). According to the pooled sample of the years 1986-87 Linnanmaa, Sanginjoki and Muhos were similar to each other with respect to their psocid assemblages whereas Taivalkoski differed significantly from Linnanmaa and Muhos (Table 3).

In 300 young spruce samples the number of psocid specimens remained far below that of old spruces because the dry weight of 28.3 $\mathrm{kg}$ of branch material gave only 55 psocids (Table 2). None of the psocid species was extremely numerous in any of the areas, Caecilius despaxi being the most common species.

\section{Discussion}

Many factors, like the distance from the sea shore, the stage of succession, edaphic factors, climate,

Table 1. The mean amount of wood material, needles and lichens (dry weight, g per branch) and contents of mean total sulphur and nitrogen ( $\mathrm{mg} / \mathrm{kg}$ of needle dry weight) in combined samples for each locality. I = Isko, $\mathrm{L}=$ Linnanmaa, $M=$ Muhos, $R=$ Rusko, $S=$ Sanginjoki, $T=$ Taivalkoski, $V=$ Vittasuo. $P$ gives the result of ANOVA

\begin{tabular}{|c|c|c|c|c|c|c|c|c|c|c|c|c|}
\hline & \multicolumn{5}{|c|}{ Old spruces } & \multicolumn{7}{|c|}{ Young spruces } \\
\hline & $\mathrm{L}$ & $S$ & M & $\mathrm{T}$ & $P$ & $\mathrm{R}$ & 1 & $\mathrm{~L}$ & V & $S$ & $\mathrm{~T}$ & $P$ \\
\hline Number of samples & 65 & 60 & 75 & 70 & & 50 & 50 & 50 & 50 & 50 & 50 & \\
\hline Wood material (g) & 678 & 587 & 659 & 654 & $>0.05$ & 38 & 34 & 36 & 43 & 38 & 44 & $<0.001$ \\
\hline Needles $(\mathrm{g})$ & 284 & 172 & 198 & 144 & $<0.001$ & 46 & 50 & 50 & 59 & 58 & 69 & $<0.001$ \\
\hline \multicolumn{13}{|l|}{ Lichens $(\mathrm{g})$} \\
\hline Hypogymnia physodes & 5.3 & 30.2 & 42.5 & 15.6 & $<0.001$ & & & & & & & \\
\hline Usnea, Alectoria sp. & 0.05 & 1.1 & 4.8 & 28.4 & $<0.001$ & & & & & & & \\
\hline Total sulphur & & & & & & 880 & 877 & 863 & 737 & 717 & 623 & $<0.001$ \\
\hline Total nitrogen & & & & & & 12173 & 11967 & 10800 & 10337 & 9663 & 9060 & $<0.001$ \\
\hline
\end{tabular}
for differences between areas. 
ground vegetation, position, etc., are possible reasons for the differences observed in the psocid fauna. Among other variables air pollution can be taken into consideration as the percentage of air impurities clearly decreases from urban to suburban and rural areas in the Oulu region in northern Finland (Anon. 1988, Tuovinen 1989). Its main effect may be caused indirectly by the occurrence of lichens and algae serving as possible food sources for psocids. The urban areas (Rusko, Isko and Linnanmaa) represent the phase where macrolichens are almost lacking, but where algae flourish instead (see e.g. Kauppi et al. 1987). This favours species which primarily live on algae. An additional food source for psocids is pollen, spores and airborne detritus which fall upon the needles and leaves. The amount of this can be increased by the sticky honeydew produced by aphids (see e.g. New 1970). This honeydew also provides crucial energy sources for diverse organisms (Mattson et al. 1989). In the course of this study it has been noticed that there

Table 2. The total number of psocids obtained from the old spruces in 1986-87 and from the young spruces in 1988. Research areas: Isko (l), Linnanmaa (L), Muhos (M), Rusko (R), Sanginjoki (S), Taivalkoski (T) and Vittasuo (V).

\begin{tabular}{|c|c|c|c|c|c|c|c|c|c|c|c|c|}
\hline & \multicolumn{5}{|c|}{ Old spruces } & \multicolumn{7}{|c|}{ Young spruces } \\
\hline & $\mathrm{L}$ & S & M & $\mathrm{T}$ & Total & $\mathrm{R}$ & I & $\mathrm{L}$ & V & $\mathrm{S}$ & $\mathrm{T}$ & Total \\
\hline \multicolumn{13}{|l|}{ Reuterellidae } \\
\hline Reuterella helvimacula (Enderlein) & 69 & 321 & 167 & 183 & 740 & 0 & 0 & 0 & 3 & 0 & 3 & 6 \\
\hline \multicolumn{13}{|l|}{ Caeciliidae } \\
\hline Caecilius burmeisteri Brauer & 249 & 80 & 103 & 21 & 453 & 2 & 6 & 4 & 1 & 23 & 1 & 37 \\
\hline C. flavidus (Stephens) & 4 & 1 & 1 & 0 & 6 & 2 & 2 & 0 & 2 & 0 & 0 & 6 \\
\hline C. fuscopterus (Latreille) & 3 & 0 & 0 & 0 & 3 & 0 & 0 & 1 & 0 & 0 & 0 & 1 \\
\hline C. despaxi Badonnel & 1 & 2 & 0 & 0 & 3 & 16 & 2 & 8 & 12 & 25 & 6 & 69 \\
\hline C. gynapterus Tetens & 0 & 0 & 1 & 0 & 1 & - & - & - & - & - & - & - \\
\hline C. piceus Kolbe & - & - & - & - & - & 0 & 0 & 0 & 0 & 1 & 0 & 1 \\
\hline \multicolumn{13}{|l|}{ Elipsocidae } \\
\hline Elipsocus abdominalis Reuter & 36 & 32 & 153 & 0 & 221 & 1 & 0 & 0 & 0 & 0 & 0 & 1 \\
\hline \multicolumn{13}{|l|}{ Psocidae } \\
\hline Trichadenotecnum majus (Kolbe) & 198 & 6 & 10 & 0 & 214 & 0 & 0 & 1 & 0 & 0 & 0 & 1 \\
\hline Metylophorus nebulosus (Stephens) & 19 & 0 & 0 & 0 & 19 & - & - & - & - & - & - & - \\
\hline Amphigerontia bifasciata (Latreille) & - & - & - & - & - & 0 & 0 & 0 & 1 & 0 & 0 & 1 \\
\hline \multicolumn{13}{|l|}{ Philotarsidae } \\
\hline Philotarsus picicornis (Fabricius) & 160 & 24 & 15 & 0 & 199 & - & - & - & - & - & - & - \\
\hline \multicolumn{13}{|l|}{ Stenopsocidae } \\
\hline Stenopsocus lachlani Kolbe & 56 & 8 & 1 & 19 & 84 & 0 & 2 & 5 & 2 & 3 & 16 & 28 \\
\hline \multicolumn{13}{|l|}{ Lachesillidae } \\
\hline Lachesilla quercus (Kolbe) & 0 & 2 & 61 & 3 & 66 & - & - & - & - & - & - & - \\
\hline L. pedicularia (Linnaeus) & 1 & 0 & 2 & 0 & 3 & - & - & - & - & - & - & - \\
\hline \multicolumn{13}{|l|}{ Mesopsocidae } \\
\hline Mesopsocus unipunctatus (Müller) & 27 & 2 & 4 & 2 & 35 & 0 & 0 & 1 & 0 & 0 & 0 & 1 \\
\hline M. laticeps (Kolbe) & 0 & 3 & 2 & 0 & 5 & 0 & 0 & 0 & 0 & 1 & 0 & 1 \\
\hline \multicolumn{13}{|l|}{ Peripsocidae } \\
\hline Peripsocus alboguttatus (Dalman) & 0 & 1 & 10 & 0 & 11 & - & - & - & - & - & - & - \\
\hline P. didymus Roesler & - & - & - & - & - & 3 & 0 & 0 & 0 & 0 & 2 & 5 \\
\hline Total adults & 823 & 482 & 530 & 228 & 2063 & 24 & 12 & 20 & 21 & 53 & 28 & 158 \\
\hline R. helvimacula juv. & 281 & 486 & 421 & 240 & 1428 & - & - & - & - & - & - & - \\
\hline C. burmeisteri juv. & 286 & 83 & 45 & 9 & 423 & - & - & - & - & - & - & - \\
\hline Unidentified juveniles & 754 & 354 & 351 & 169 & 1628 & - & - & - & - & - & - & - \\
\hline Total juveniles & 1321 & 923 & 817 & 418 & 3479 & 50 & 49 & 30 & 123 & 77 & 68 & 397 \\
\hline Total & 2144 & 1405 & 1347 & 646 & 5542 & 74 & 61 & 50 & 1441 & 130 & 96 & 555 \\
\hline
\end{tabular}




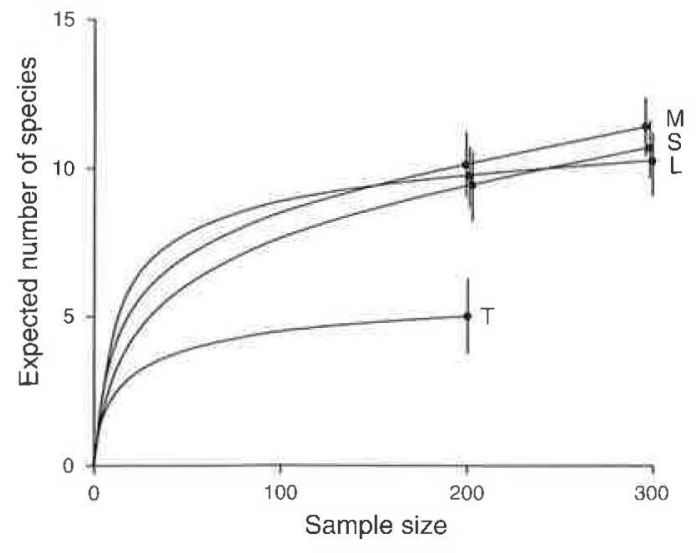

Fig. 2. Expected species number, estimated by rarefaction in the four study plots of old spruces as a function of the sample size. Vertical lines indicate $S D$.

are significantly more aphids in the vicinity of the most polluted areas (Orell et al. 1987, Laine et al. 1990) as has also been noted elsewhere in similar studies (Villemant 1981, Braun \& Flückiger 1984, Dohmen 1985).

Reuterella helvimacula is considered to feed primarily on lichens, secondarily on Pleurococcus and on fungal spores (Broadhead 1958, Günther 1974, Turner 1983), and also on green algae (Gilbert 1971). It was scarce on young spruces and also on the most urban areas where macrolichens were almost lacking. Its highest occur-

Table 3. Similarity of psocid assemblages of Linnanmaa, Sanginjoki, Muhos and Taivalkoski compared with Renkonen index using pooled data of 1986-87. Results of $t$-tests also given (NS = not significant).

\begin{tabular}{|c|c|c|c|}
\hline & Linnanmaa & Sanginjoki & Muhos \\
\hline Sanginjoki & $\begin{array}{l}0.703 \\
t=1.43, d t=11 \\
\text { NS }\end{array}$ & & \\
\hline Muhos & $\begin{array}{l}0.618 \\
t=2.01, d f=11 \\
\text { NS }\end{array}$ & $\begin{array}{l}0.771 \\
t=1.00, d f=4 \\
\text { NS }\end{array}$ & \\
\hline Taivalkoski & $\begin{array}{l}0.438 \\
t=3.66, d f=4 \\
P<0.05\end{array}$ & $\begin{array}{l}0.537 \\
t=2.35, d t=4 \\
\text { NS }\end{array}$ & $\begin{array}{l}0.473 \\
t=2.99, d f=4 \\
P<0.05\end{array}$ \\
\hline
\end{tabular}

rence was among the old spruces of Sanginjoki where the macroscopic epiphytic lichen Hypogymnia physodes (L.) was also abundant.

On old spruce branches Stenopsocus lachlani, Mesopsocus unipunctatus, Metylophorus nebulosus and especially Trichadenotecnum majus and Philotarsus picicornis increased towards urban areas. $M$. unipunctatus is considered to feed on algae or spores (Broadhead 1958, Broadhead \& Wapshere 1966, Turner 1983), and Schneider (1979) correlates it with dead branches. It is often sampled from deciduous trees (Hedström 1983). P. picicornis is reported to live on the trunks of several coniferous and broad-leaved trees (Günther 1974, Nyholm 1983, Hedström 1983) and on the bark of branches (Schneider 1979), feeding on algae and spores (Broadhead 1958, Broadhead \& Wapshere 1966).

Caecilius burmeisteri was found in all the study areas both on old and young spruce branches. However, on old spruces its occurrence was most abundant in the most urban area at Linnanmaa. The species has been reported from coniferous trees (Hedström 1983) where it is said to be concentrated on dead branches (Guinther 1974) or on the living parts of the branches (Schneider 1979).

Elipsocus abdominalis was most abundantly found at Muhos. On the other hand it was totally lacking from the most rural area, Taivalkoski. Its feeding habits seem to be poorly known. Günther (1974) considers it a close relative of Elipsocus mclachlani which, according to his observations, prefers dead or dying conifers. Gilbert (1971) considers E. mclachlani an obligate lichen feeder, while Broadhead \& Thornton (1955) and Broadhead (1958) confirm that it also feeds on algae (Pleurococcus), in addition to lichens on dead twigs. The distribution of E. abdominalis in our samples seems to point to the use of both food items.

The majority of those species which in our study were obtained in low numbers are not reported as living on conifers (see New 1970, Günther 1974, Hedström 1983, Thornton 1985).

This study revealed that there are certain differences in the number and species composition of psocids on old and young spruce branches in northern Finland. Differences also exist between areas, some species being concentrated in urban 
and others in more rural areas. The occurrence of algae and lichens seems to be correlated with the species composition. Conclusions on the possible relation between air pollution and psocids are hard to establish. Certain correlations, however, seem to give good reason for future studies.

Acknowledgements. We wish to thank Martin Meinander, who kindly helped us in determining some of the psocid species. Arja Itämies and Päivi Tanner were of immense help in the handling of the branch and needle material. The work was supported by the Academy of Finland and by grants from the University of Oulu. Two anonymous referees made valuable comments on our manuscript.

\section{References}

Anonymous 1988: Oulun ilmanlaatu. Päästökartoitus 1987. [Air quality of Oulu. Emission mapping 1987] (In Finnish) — Oulun kaupunki, ympäristönsuojelutoimisto. Julkaisu 1/1987:1-30.

Braun, S. \& Flückiger, W. 1984: Increased pollution of the aphid Aphis pomi at a motorway: Part I - Field evaluation. - Environ. Poll. 39:183-192.

Broadhead, E. \& Thornton, I. W. B. 1955: An ecological study of three closely related psocid species. - Oikos 6:1-50.

Broadhead, E. 1958: The psocid fauna on larch trees in northern England - an ecological study of mixed species populations exploiting a common resource. J. Anim. Ecol. 27:217-263.

Broadhead, E. \& Wapshere, A. J. 1966: Mesopsocus populations on larch in England - the distribution an dynamics of two closely related coexisting species of Psocoptera sharing the same food resource. - Ecol. Monogr. 36:327-383.

Dohmen, G. B. 1985: Secondary effects of air pollution: enhanced aphid growth. - Environ. Poll. 39:227-234.

Gilbert, O. L. 1971: Some indirect effects of air pollution on bark-living invertebrates. - J. Appl. Ecol. 8:77-84

Günther, K. K. 1974: Staubläuse, Psocoptera. - Tierwelt Deutschlands 61:1-314.

Heck, K. L., van Belle, G. \& Simberloff, D. 1975: Explicit calculation of the rarefaction diversity measurement and the determination of sufficient sample size. Ecology 56:1459-1461.

Hedström, L. 1983: Bidrag till kunskapen om svenska Psocoptera. (Contribution to the knowledge of Swedish Psocoptera). - Entomol. Tidskr. 104:83-86.

Huldén, L. 1984: A check list of the Finnish insects. Small orders. - Notulae Entomol, 64:1-29.

James, F. C. \& Rathbun, S. 1981: Rarefaction, relative abundance, and diversity of avian communities. Auk 98:785-800.
Kauppi, M., Mikkonen, A. \& Halonen, P. 1987: Condition of the epiphytic lichen vegetation of Oulu and its surroundings (in finnish with an english abstract). Aquilo, Ser. Bot. 25:61-67.

Laine, A., Orell, M. \& Itämies, J. 1990: Invertebrate fauna on Norwegian spruce (Picea abies) branches in northern Finland. - Entomol. Fennica 1:193-199.

Mattson, W. J., Haack, R. A., Lawrence, R. K. \& Herms, D. A. 1989: Do balsam twig aphids (Homoptera: Aphididae) lower tree susceptibility to spruce budworm? - Can. Entomol. 121:93-103.

New, T. R. 1970: The relative abundance of some British Psocoptera on different species of trees. - J. Animal Ecol. 39:521-540.

- 1971: An introduction to the natural history of the British Psocoptera. - Entomologist 104:59-97.

Nyholm, T. 1983: Psocoptera on the alvar of Öland. Entomol. Tidskr. 104:96-100.

Orell, M., Laine, A. \& Itämies, J. 1987: Ilman epäpuhtaudet ja kuusen evertebraattieloyhteisöt (Air pollution and the invertebrate community of Norwegian spruce). Aquilo, Ser. Bot. 25:117-123.

Pesenko, Yu. A. 1982: [Principles and methods for quantitative analysis in faunistic research] (In Russian) Izdvo Nauka, Moskva. 287 pp.

Renkonen, O. 1938: Statistisch-ökologische Untersuchungen über die terrestrische Käferwelt der finnischen Bruchmoore. - Ann. Zool. Soc. Zool.-Bot. Fenn. Vanamo 6:1-231.

Schneider, N. 1979: Les psocoptéres du Grand-Duché de Luxembourg. II. Faunistique et écologie des espéces sylvicoles du Kalebierg. - Bull. Ann. Soc. R. Belge Entomol. 115:197-208.

Thornton, I. W. B. 1985: The geographical and ecological distribution of arboreal Psocoptera. - Ann. Rev. Entomol. 30:175-196.

Turner, B. D. 1983: Annual respiration and production estimates for collembolan and psocopteran epiphyte herbivores on lark trees in southern England. - Ecol. Entomol. 8:213-228.

Tuovinen, J.-P. 1989: Tarkennettu Euroopan rikkitase 1985. [Defined sulphur balance in Europe] (In Finnish) In: Kulmala, A. \& Ryaboshapko, A. (eds.): Ilman pilaantuminen Itämeren alueella. Epäpuhtauksien kulkeutuminen ja niiden vaikutus ympäristöön. [Air pollution in the Baltic area. Spreading of impurities and their environmental impact] Leningrad Gidrometeoizat 1989:1-256.

Villemant, C. 1981: Influence de la pollution atmospherique sur les populations d'aphides du pin sylvestre en foret de Roumane (Seine-maritime). - Environ. Poll. 24:245-262.

Wolda, H. 1981: Similarity indices, sample size and diversity. _ Oecologia (Berl.) 50:296-302.

Received 1.II.1993 